\title{
Issues and Perspectives Related to Mobile Brand Marketing in Thai Private Higher Education
}

\author{
Dr Paul TJ James \\ Graduate School, Bangkok University, Bangkok, Thailand \\ Tel: 66-23-503-500Ｅ-mail: paul.j@bu.ac.th
}

\begin{abstract}
Research on m-Branding in higher education appears to be in its infancy, as little empirical research has been conducted specifically targeting branding in higher education. University branding strategy, technology issues, and stakeholder branding issues are discussed which forms the model that underpins that qualitative inquiry of six private university managers involved in university marketing practices.

The definition of m-Branding was adopted and fine-tuned in this paper to mean the delivery of electronic brand media, support materials and messages to mobile devices perceived as relevant to stakeholder/student segments. In this paper, the implications for branding developments through mobile technologies are discussed; and concludes with a discussion of the future of m-Branding reflecting a useful managerial tool that requires a more integrated approach in the Thai higher education system that results from a combination of technology, software, staff development and consequent student engagement.
\end{abstract}

Keywords: M-Branding, Higher education, Marketing, Branding strategy, Technology 


\section{Introduction}

Marketing for Thai higher education institutions now involves both a domestic, and also an international focus (Cubillo, Sanchez, \& Cervino, 2006), although this wasn't always seen as necessary or desirable (Gray, 1991). However, branding in Thai higher education is inclined to be perceived along the lines of university names and which are not conceived in terms of any individual programme branding developments the way tangible products do (Turley \& Moore, 1995). Little has been written about the use of electronic mobile devices in branding developments; and within the sphere of Thai higher education research is perhaps somewhat more limited. As such research on branding in higher education appears to be in its infancy ((Hemsley-Brown \& Oplatka, 2006), as little empirical research has been conducted specifically targeting branding in higher education (Gray, Fam, \& Llanes, 2003). Further, the research literature on management views of m-Branding regarding Thai universities also appears to be somewhat poor, if not non-existent.

Ally (2004) defined m-learning as the delivery of electronic learning materials to mobile devices; and this is fine-tuned in this paper to mean m-Branding as the delivery of electronic brand media, support materials and messages to mobile devices perceived as relevant to stakeholder/student segments that enhance their learning opportunities and requirements.

\subsection{Operating University Branding Strategy}

Higher education markets in Thailand have seen a rise in competition mirroring overseas developed markets (Foskett, 2002; Freeman \& Thomas, 2005) resulting in changes to recruitment strategies (Canterbury, 1999) which is perceived as consequent upon declining student numbers (MacGregor, 2000) arising from on-going recessive pressures and the need to address new quality assurance developments (Wernick, 2006). Branding practices in Thai universities has therefore become a contemporary institutional behaviour (based on Wæraas, 2008), seen as a dominant and important theme in the oversupplied Thai pedagogic market (Twitchell, 2002). The long-term effects of these drivers on competition between universities (based on Foskett, 2002) has led to general concern about the possible impacts of the growing marketisation (Williams, 1995) of higher education and has promulgated the need for Thai universities to differentiate themselves both domestically and internationally from the competition (Cubillo et al., 2006). Thus, most Thai higher education institutions have experienced the effects of consistent declines in their student enrolments (based on MacGregor, 2000), highlighting the central, if not primary, role of brand marketing in student recruitment practices (Tagwireyi, 2000; Smith, Scott, \& Lynch, 1995). Adding to increased competition are the affects of the world-wide recession that not only contributes to less student numbers but also challenges Thai universities to make more effective strategic choices relative to programme offerings.

The above initiates new challenges for Thai university management because of an increasingly competitive higher education environment (Binsardi \& Ekwulugo, 2003), as many universities in Thailand have now also begun to realise the importance of having sound marketing strategies to stay competitive (Ho \& Hung, 2008). University management may find that ...it is generally difficult to develop a strong brand identity, harder with services than products, and particularly difficult with an infrequent service purchase (Hesketh \& 
Knight, 1998), such as with prospective stakeholders/students. However, marketing practices traditionally involved the utilisation of specific techniques such as advertising, market research and "low-level branding” (Caruana, Ramaseshan, \& Ewing, 1999) meaning marketing behaviour related to the partial adoption of branding techniques designed to enhance the university's overall image and is consistent with behaviour changes reported from past research findings into the competitive advantage of service industries (Aaker, 1991). Additionally, potential changes to Thai governmental educational policy (MOE, 2008) which supports reduced funding for major universities, has led to an increased need for marketing initiatives through the inevitable market reform (British Council, 2008) in order to encourage increased student recruitment through an opportunistic privatisation agenda (Meek \& Wood, 1997). Robust international education brands have started to evolve (Gray, Fam, \& Llanes, 2003b; Mazzarol, 1998) and this puts pressure on the Thai international higher education student market as it is perceived by many to be in the developmental stage (Maringe, 2005) and by association so is the Thai university branding developments (Judson, Aurand, \& Gorchels, 2006).

Connecting with the targeted stakeholder/student with a consistent message is thus a new imperative for Thai higher education marketers and correspondingly sets a difficult marketing challenge (Rishi, 2007). The effects of stakeholder/student perceptions of university programme offerings (Eagle \& Brennan, 2007) and the brand image conveyed needs to be managed appropriately (Ivy, 2001; Nicholls, et al., 1995). As a result, it has become an operational imperative for universities to market themselves to interested stakeholders - the most important of which are students and their opinions (Lancaster \& Reynolds, 2002) directly through contemporary marketing techniques using modern technologies such as mobile media and focused database marketing (Tapp, Hicks, \& Stone, 2004). Consequently, branding matters (Mazzarol \& Soutar, 2001) in terms of the perceived meaning of the university name or logo as brands relate the identified product/service attributes to perceived segment needs (Ind, 2003); to help consumers distinguish products/services from the competition (Aaker, 1991); reinforce buying actions (Kapferer, 2004); reduces stakeholder/student confusion (Kapferer, 1995); adds to a buyers perceptual needs in terms of status/prestige (Jiang, 2004) and is part of the value proposition designed into the communications process between the consumer and the brand (Aaker, 1996). Ultimately, successful university brand management is anticipated to result in increased student retention rates (Belanger, Mount, \& Wilson 2002). This raises the context for the first research question - how do university management view contemporary branding developments in Thai private higher education?

\subsection{Stakeholder Branding Issues}

While the notion and practice of m-Branding is considered an emerging phenomenon in current brand management (igi-global.com, 2008), it is nevertheless underpinned by appropriate CRM concepts (Baker, 2003) as internet technologies are considered a useful tool in building brand awareness (Samiee, 1998). In this paper, m-Branding is not just considered to be about branding using portable devices, but branding across digital and cultural contexts (Madu \& Jacob, 1999). As such, Kramer, Noronha, and Vergo (2000) indicates that 
technologies linking identified market segment needs to digital offerings have now become commonplace where newer technologies tend to influence people's decisions (Winkler, 1999) resulting in a greater pervasion of techno-social interaction. At universities, this is attributed to an innovative and practical extension of visible e-learning practices through the use of mobile phones (Nyiri, 2002) as students appear to like the appeal of multimedia delivery (Wood, Tapsall, and Soutar, 2005) and is thus considered another branding channel (Bleimann, 2004) for utilising marketing practices where an early e-learning orientation corresponds with early branding developments (Hambrecht \& Co, 2000). Benady (2005) suggests that there is no such thing as a global consumer, and this can be translated into m-Branding, as there is no such entity as a global student - so each targeted segment has to be faultlessly derived in order to ensure appropriate brand awareness and development. This raises the context for the second research question - what are the implications of managerial views on continuing stakeholder brand development in Thai private higher education?

\subsection{Technology Issues}

When using the m-Branding definition as meaning m-Branding as the delivery of electronic brand media, support materials and messages to mobile devices perceived as pertinent to stakeholder/student segments, this raises some issues. For example, targeting remains one of the ubiquitous problems of electronic media personalisation developments (Perugini \& Ramakrishnan, 2003) through which to deliver appropriate adjustments in brand content provision. Numerous researchers have discussed digital system developments (Petsas, et al., 2001; Cheng et al., 2000; and, Tsai, Tseng, \& Chen, 2000) and have shown how user data can be used to provide appropriate content/information streams that match targeted user needs. More appropriate to this paper, Zhang and Shijagurumayum (2003) used the concept of user metadata as a profile underpinning the delivery of targeted and customized content to mobile-phone users. This has not been lost in pedagogic developments, as research has focused on how students may be assisted in receiving individualised and personalised knowledge content (Dahn \& Schwabe, 2002) whether as assisted-learning in the classroom (Carchiolo, et al., 2003) or through distance-learning programmes (Qu \& Shen, 2002; and, Dadarlat, Coffey, \& Ivan, 2002). Consequently, it has become an operational imperative for universities to market themselves to interested stakeholders (Freeman \& Thomas, 2005) - the most important of which are students and their opinions (Lancaster \& Reynolds, 2002) directly through contemporary higher technologies such as mobile devices (Tapp et al., 2004). This raises the context for the third research question - why is there a need for branding developments targeted to stakeholder/student mobile devices in Thai private higher education? 
These three major aspects are depicted in Figure 1, below.

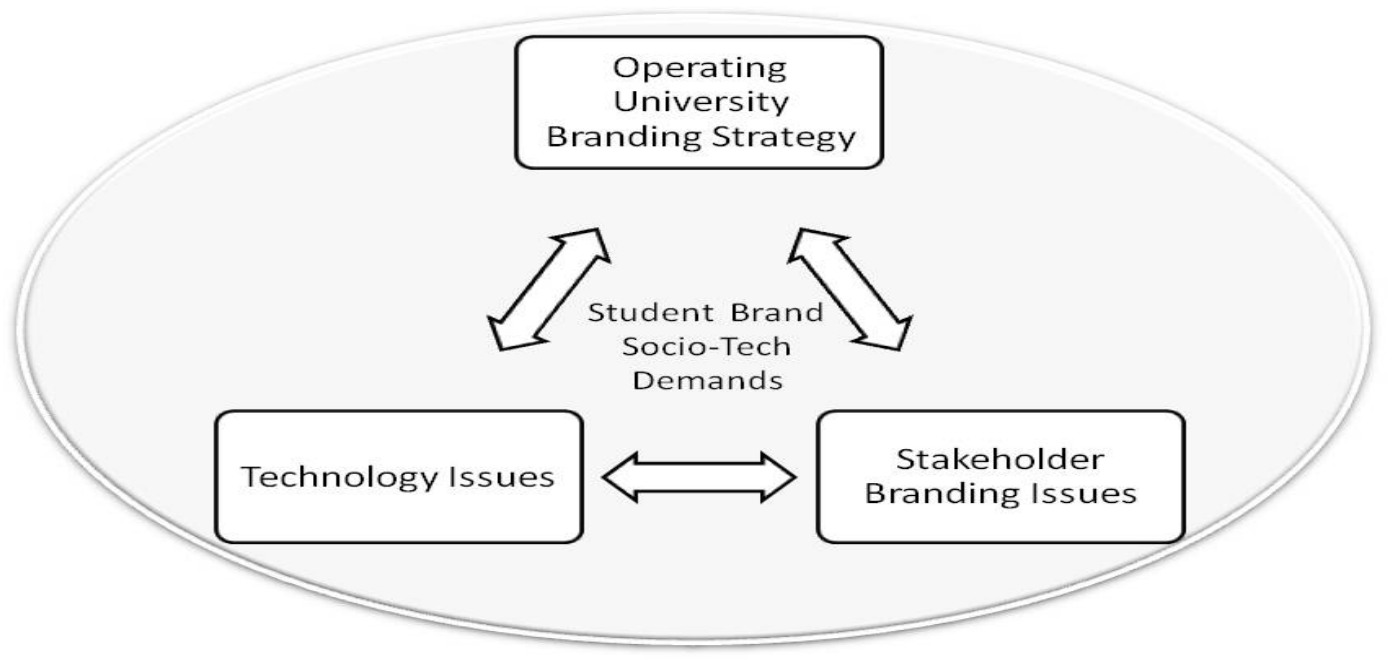

Figure 1. Major Literature Issues

m-Branding helps target marketing activities effectively to one student - as long as the appropriate data channels are utilised. As such a likely developing issue is that personalisation of branding media requires a personalised target - and there is nothing more personal than a student's own mobile device.

\section{Methodology}

To consider more implicitly the issues and questions raised, this empirical groundwork utilised an interpretive approach to understand the perceptions of university marketing management experiences in Thai private universities (Walsh, White, \& Young, 2008) using a semi-structured questionnaire providing an appropriate element of context and flexibility (Cassell \& Symon, 2004). Given the lack of purposeful research in this area, this methodology is seen as appropriate to generating contextual data for the purpose of creating richer theory development (Cayla \& Eckhardt, 2007).

The population for this study was international college managers in twelve private universities in Bangkok (based on Carman, 1990). The criteria of theoretical purpose and relevance (Glaser \& Strauss, 1967) were applied to the population and using Glaser's (2004) sampling processes nine universities were approached. However, three declined for a number of reasons which related mostly to a lack of interest in mobile branding; and three did not respond. Six college managers were thus determined as the resultant sample frame which could be considered convenience sampling after Harrel and Fors (1992). Interviews were conducted in English and took approximately one hour. All interviews were recorded on audio-tape after gaining explicit permission, and were later transcribed verbatim. The conduct of the interviews follows a similar process used by Gray and Wilcox (1995), with each individual group being asked the same set of questions - modified through ancillary 
questioning (probes and follow-ups) in the same way as Balshem (1991). To increase the reliability of the data, the actual transcription was returned to each respondent for correction, addition or deletion and return, which followed the process of validated referral (Reeves \& Harper, 1981). Whole-process validity was achieved as the respondents were considered professionals (Tull \& Hawkins, 1990) and knowledgeable of the context and content associated with the research orientation.

Each interview was initially manually interrogated and coded initially using the Acrobat search engine software according to sub-themes that 'surfaced' from the interview dialogue using a form of open-coding derived from Glaser (1992a) and Straus and Corbin (1990); and also by using a checklist matrix based on Miles \& Huberman (1994). This treatment was also reinforced and extended through the use of thematic analysis conducted using the NVivo qualitative software package (Walsh et al., 2008). Each interview was treated and coded independently. In this way, no portion of any interview dialogue was left uncoded and the overall outcome represented the shared respondents views and perspectives through an evolving coding-sequence (Buston, 1999). Various themes were sensed from the use of this package, as well as from the initial manual-coding. This dual form of interrogation was an attempt to increase the validity of the choice of both key themes and sub-themes through a triangulation process. NVivo was further used to explore these sub-themes by helping to pull together each of these sub-themes from all the interviews (Harwood \& Garry, 2003). In this way, it was possible to capture each respondent's comments on each supported sub-theme and place them together for further consideration and analysis.

\subsection{Presentation of Research Outcomes}

The scope of the sub-theme observations can be seen in Table 1, below:

Table 1. Sub-theme observations

\begin{tabular}{|c|c|c|c|c|}
\hline $\begin{array}{c}\text { Major Theme / } \\
\text { University }\end{array}$ & $\begin{array}{c}\text { Operational } \\
\text { University } \\
\text { Branding } \\
\text { Strategy }\end{array}$ & $\begin{array}{c}\text { Mobile } \\
\text { Technology } \\
\text { Concerns }\end{array}$ & $\begin{array}{c}\text { Stakeholder } \\
\text { Branding } \\
\text { Issues }\end{array}$ & Total \\
\hline A & 5 & 6 & 4 & 15 \\
\hline B & 3 & 7 & 9 & 19 \\
\hline C & 2 & 4 & 3 & 9 \\
\hline D & 3 & 3 & 7 & 13 \\
\hline E & 7 & 8 & 5 & 20 \\
\hline F & 5 & 6 & 3 & 14 \\
\hline Total & 25 & 34 & 31 & 89 \\
\hline
\end{tabular}


Table 2. Research Questions and Major Themes

\begin{tabular}{|c|c|c|}
\hline Research Question & Major Themes & Sub-Themes \\
\hline \multirow{4}{*}{$\begin{array}{l}\text { How do university management view } \\
\text { contemporary branding strategy } \\
\text { developments in Thai private higher } \\
\text { education? }\end{array}$} & \multirow{4}{*}{$\begin{array}{l}\text { Operational } \\
\text { University Branding } \\
\text { Strategy }\end{array}$} & Brand Rationale \\
\hline & & Brand Message \\
\hline & & Push Advertising \\
\hline & & Brand Recognition \\
\hline \multirow{9}{*}{$\begin{array}{l}\text { What are the implications of } \\
\text { managerial views on technology } \\
\text { and continuing brand } \\
\text { development in private } \\
\text { universities in Thailand? }\end{array}$} & \multirow{9}{*}{$\begin{array}{l}\text { Mobile Technology } \\
\text { Concerns }\end{array}$} & Software Development \\
\hline & & Support \\
\hline & & Development Costs \\
\hline & & Technological Flexibility \\
\hline & & Access \\
\hline & & Training \\
\hline & & Privacy \\
\hline & & Coverage and Infrastructure \\
\hline & & Integration \\
\hline \multirow{6}{*}{$\begin{array}{l}\text { Why is there are need for } \\
\text { branding developments targeted } \\
\text { to stakeholder/student mobile } \\
\text { devices? }\end{array}$} & \multirow{6}{*}{$\begin{array}{l}\text { Stakeholder Branding } \\
\text { Issues }\end{array}$} & Flexibility \\
\hline & & Interactivity \\
\hline & & Students Needs \\
\hline & & Convenience \\
\hline & & Personalisation \\
\hline & & Student Costs \\
\hline
\end{tabular}

\section{Research Outcomes}

The style adopted for reporting and illustrating the data is influenced by Gonzalez (2008) and Carpenter (2008) and is discussed below, concentrating on the research questions. This is done to ensure integration of the data directly with the themes discussed and are shown to further the completeness and robustness of the research methodology adopted.

\subsection{Operational University Branding Strategy - Main Theme 1}

How do university management view contemporary branding strategy developments in Thai private higher education? This question is underpinned by the discussion surrounding the sub-themes of Brand Rationale; Brand Message; Brand Recognition; and Push Advertising:

\subsubsection{Brand Rationale}

The main outcomes of this research strongly support the necessity for management to become aware of the need to engage more effectively with stakeholders (Trim \& Lee, 2006) illustrated by one respondent (University E) in that the ...issues are complex. Students are technologically aware. We can take advantage of this, because if we don't - some other university will. Since brand marketing in Thai higher education appears to be in its infancy, stakeholders/students could be encouraged to unify behind a brand strategy that fits in with their segment orientation (Trim \& Lee, 2006). Brands appear to require acceptance and 
growth in order to create a strong brand (Gilbert, Child, \& Bennett, 2001) in terms of security (Temporal, 2000) and benefits (Ind, 2003), as shown by one respondent (University F) ...our brand has to be credible. It has to be seen as a living issue that is reinforced by... by what we do... by everybody who works here... by students getting what we say we will provide...

When asked what branding strategies were utilised, the overall reported response was only towards the university as a singular brand identity (Delamothe, 2000; Kapferer, 1992) - very little, if any, was directed to programme brands (based on Swaminathan, Fox \& Reddy, 2001) such as an MBA. This is typified by one respondent (University D) who reported that ...we haven't got around yet to devise a way to separate out the university from the degrees we offer... we only use one umbrella and that is us...

\subsubsection{Brand Message}

When asked what the most important brand message the university was conferring, the reply was to inform and support (Ghodeswar, 2008). This is typified by one respondent (University C) who stated that ...Our marketing ethos has to be to continually match segment needs... the message has to be consistent. Unfortunately, we sometimes gets it wrong... and this has implications because there is another university just a block away... This is perhaps a major recognition of the effects of branding (Chipkin, 1997) on overall university strategy, as typified by one respondent (University E) who states ...We have to monitor, assess, re-strategise and then make sure that we listen to what students want. Otherwise they will go to the competition.

\subsubsection{Push Advertising}

Brand development at universities appears to be commercially and professionally different from marketing or advertising development, as the model of HE market engagement becomes more technologically conscious. One respondent (University A) indicated that...The constant stream of advertising from many sources makes students indifferent to our message. We need to get close to them - and get personal... Another respondent (University C) indicated that ...from our perspective this is all new. I mean... we need to use technology to get the message over, but at the moment it is all one way... I don't know what else to do... it's just another marketing channel that we're learning about... Consequently, this supports the notion that managers appear to think that university branding operates in the same schema as push-advertising. However, this may be detrimental to the whole notion of brand development (Gilbert et al., 2001) and any consequent new ways of building relationships with customers (Trim \& Lee, 2006) as advertising is considered one-way communication, whereas branding is at least a two-way process. However, one respondent (University B) realised that...I notice that some students don't like being sent messages too much. However, targeted messages linking good PR with student needs and program notices, will help with brand support I'm sure... In this respect push-advertising works, but only for intentional and targeted messages that have the appropriate content that the target segment regards as essential to their everyday requirements. This is illustrated for example, by one respondent (University F) who indicated that ...One major problem is of course, brand content. We have to be careful to match their technology, otherwise the message may be garbled and we will 
have lost a branding opportunity...

\subsubsection{Brand Recognition}

It was recognized that management had a brand responsibility (Ghodeswar, 2008) to continually assess developments in university brand recognition outcomes (Kärreman \& Rylander, 2008). This is typified by one respondent (University A) who states that ... We need to develop sustainable advantage over our competitors and one way to do just this is connecting directly with students. Of course, we have to train our staff too, but fundamentally this has to be directed at the student segment. This is supported by another typical statement by one respondent (University D) who states that ...In essence, our marketing practices must change. We have to get inside their heads. Our name must be in their eyes... they have to know of us intimately...

Building brands that have sustainable advantage (Chernatony \& McDonald, 1998) and connecting directly with students in order to continually match segment needs (Ghodeswar, 2008), as one respondent (University C) highlighted it ...appears to be a major requirement in the construction and reinforcement of the university brand strategy; otherwise students today will go elsewhere... This leads to the brand extension of the various programme offering such as multiple MBA programme provision (Bhat, Kelley \& O’Donnell, 1998).

\subsection{Mobile Technology Concerns - Main Theme 2}

What are the implications of managerial views on technology and continuing brand development in private universities in Thailand? This question is underpinned by the discussion surrounding the sub-themes of Software Development; Support; Development Costs; Technological Flexibility; Access; Training; Privacy; Coverage and Infrastructure; and Integration:

\subsubsection{Software Development}

This was raised as an essential issue (Schwabe, Rossi \& Guimaraes, 2002) in the support of branding developments. This was typified by one respondent (University C) who indicated that ...One of our major priorities is to define and develop software that we can use safely and seamlessly that supports our use and student employment of the various mobile technologies. Another respondent (University B) indicated however that ... Staff need more training in order to adjust available software that is useful to students... and another respondent (University E) supported this notion and suggested that ...I think that we lack testing capability as it is difficult to know how our messages are being seen by students with so many mobile devices available... This was seen to compound the issue of flexibility, access, privacy, personalisation (Jeevan \& Padhi, 2006) and raised the issue of cost concerns (Ally, 2004) as discussed later.

\subsubsection{Support}

On the issue of support (Groves, Jarnigan \& Eller, 1998), one respondent (University E) indicated that ...it is essential - not only for staff, but also for students... as not everyone can utilise the available software and hardware effectively. This raised the notion of appropriate 
support when building brand levels, as one respondent (University B) indicated that ...inevitably, support levels will determine how effective our brand strategies are... Since student capability and mobile technological scope provides an enormous management issue for university managers, it would appear that support levels (Collis \& Moonen, 2001) may be a key aspect of the personification of each unique university brand strategy.

\subsubsection{Development Costs}

In the present economic conditions costs were raised as a particular problem. As one respondent (University F) indicated that ... Whatever, the cost, we have to pay it. We need to help students understand our brand... ....we need students to remember our brand... ...to make the brand visible for life-long learning...

Further, another respondent (University B) indicated that ...We are concerned that cost increases which are beyond our control will reduce our technology use, but our strategy is to connect to students - so we must absorb this cost... thus signifying that the costs associated with connecting to students is a must strategy, rather than an add-on strategy.

\subsubsection{Technological Flexibility}

It was recognised that technology flexibility (Daniel, 2000) was a key factor in managing stakeholder perceptions of the university brand, as typified by one respondent who indicated that ... We need to innovate to really communicate our brand. We need to change our style; our ethos; and most of all we need to change how we deal with students, learners, parents, employers and of course with our staff. Technology is the major driver for this (University C).

\subsubsection{Access}

An obvious issue of access (Gilbert, 2006) by students was raised, although this was more complicated as it required other issues to be managed effectively e.g. flexibility, cost and support. Consequently as one respondent (University C) indicated that ...Gaining access is a big issue, because when we send a message to them, they will turn off, if they can't access what it is that we send... And to illustrate the interference of the technological gateway another respondent (University E) indicated that ... We have to make it easier for students to respond and that means training them to access easily the system. We need to make it simple - but also secure - that is the challenge...

\subsubsection{Training}

Training issues were highlighted for both university staff and students as any software required for the smooth operational interface needed to be simple (Jeevan \& Padhi, 2006) and secure in order to support the branding message (Trim \& Lee, 2006; Bleimann, 2004). For example, one respondent (University D) indicated that ...We have carried out some training mostly on ICT skills - but we need more in terms of understanding students needs... and this was further supported by another respondent (University A) who indicated that ...Students need to trained to pick up and open our media messages. Although many students can do this, they need help to respond successfully... 


\subsubsection{Privacy}

Privacy and security issues (Barnes, 2002) were raised and typified by one respondent (University E) who indicated that ...I'm concerned that some students may perceive that our message might be an intrusion... Whilst this may raise a problem of intrusion, as one respondent (University B) indicated that ...We recognise that privacy issues are paramount and that m-Branding activities may incline students to perceive our brand in a negative way... Another privacy issue that was raised related to personal data management and this is illustrated by one respondent (University F) who indicated that ... We try to assure all our students that personal data is kept secret and will never be made available to third parties. Obviously this is an issue that we are aware of when students utilise our wireless applications...

However, another respondent (University C) admits that ...Unfortunately, encryption appears to slow messages through the system and as such are difficult to manage...

\subsubsection{Coverage and Infrastructure}

This issue was raised following highlighted concerns of coverage leading to infrastructure problems. This is highlighted by one respondent (University D) who indicated that ...Our messages are sent without knowing where our students are geographically - they me be on campus, on a train, bus or at home. We have no way of knowing... Thus, given the fractured state of mobile technology services in Thailand, it is a continuing concern for university managers. For example, one respondent (University A) indicated that ...Our messages must permeate across the city, and we rely on our service providers to get our message out. Unfortunately, outside Bangkok, that may not be feasible or practical...

The data from respondents thus suggests that coverage (Olatokun \& Bodunwa, 2006; Wainwright, 2005) and any corresponding infrastructure (Gibbons, 1998) may influence how the message was delivered and its viable content, indicating that technology understanding was a crucial requirement in ensuring appropriate flexible m-Branding developments and opportunities (Hamann, Williams, \& Omar, 2007). This raises the notion that the service provider may unduly influence student's perception of the message, irrespective of the designed message intent.

\subsubsection{Integration}

One major issue that was raised was integration (Harrison et al., 2002). This is exemplified by one respondent who indicated (University C) that ...Significantly, we have to ensure a diversified message that is seamlessly integrated into the various mobile technologies that are used... Seamless integration issues would therefore influence the how and the what of the branding message (Cunningham et al., 2003). Integration would also affect other key aspects such as costs and technological variety associated with student perceptions.

\subsection{Stakeholder Branding Issues - Main Theme 3}

Why is there a need for branding developments targeted to stakeholder/student mobile devices? This question is underpinned by the discussion surrounding the sub-themes of Flexibility, Interactivity, Students Needs, Convenience, Personalisation and Cost: 


\subsubsection{Flexibility}

Flexibility was raised as a major issue that affected both course/media development and the student learning experience (Gibb, 1996). In this respect, as typified by one respondent (University D) who indicated that ...As students have different mobile phones, they will have different capabilities. We cannot please everyone... which suggests that associated problems affected student/university relationships as well as the learning experience (as claimed by Daniel, 2000). For example, another respondent (University B) indicated that ...Do we provide high level graphics and video, when only $22 \%$ of our students have devices that can receive this. Consequently, student mobile phones limit what we can do - and unfortunately this creates a difficulty because students often change their phones...

\subsubsection{Interactivity}

Where student mobile technologies matched the offering produced by the university there appeared to be a positive response through greater student engagement when good connection speed was available (Sekikawa et al., 2001) and with adequate bandwidth (Keegan, 2003). For example, one respondent (University A) indicated that ...The technology of today's mobiles are excellent. This helps us introduce levels of interactivity we could only imagine 2 years ago... and that this recognition is a vital component in the university marketing effort.

\subsubsection{Students Needs}

The data indicated that those universities matching student needs (James, 2008) may have greater penetration in m-Branding developments as students want to be connected (Rishi, 2007). This is typified by one respondent (University E) who indicated that ...no one is connecting with students. They appear distant in terms of our marketing effort. We have to do something... .... when we do, they can't get enough of it...

\subsubsection{Convenience}

Technological issues were raised in response to questions surrounding convenience. This was not only in terms of timing, but also in terms of speed and flexibility in content (Petsas et al., 2001). For example, one respondent (University $\mathrm{C}$ ) indicated that ...We have to support the brand image of the university; but this must be done at times and places when it is convenient for each segment - that is, when students are best placed to take advantage of our branding strategy...

\subsubsection{Personalisation}

It was recognised by managers that personalisation (Wilson \& Velayutham, 2008) was not only an opportunity, but also a strategic necessity, as depicted by one respondent (University A) who indicated that ...Every student is different and requires different things. For example, younger students behave differently to older students. We can't send the same message to everyone... In this way, managers appeared to accept that they had to deal with different marketing segments - even in the same cohort and that the content and media needed to be flexible and targeted (Perugini \& Ramakrishnan, 2003). For example, one respondent (University D) indicated that ...We can't treat all students the same. Brand personalisation 


\section{Macrothink}

Journal of Management Research

ISSN 1941-899X

2011, Vol. 3, No. 1: E4

recognises this and facilitates an on-line experience that ensures students keep coming back...

\subsubsection{Student Costs}

The issue of cost associated with returning messages (Mahoney, 1998) was raised and depicted by one respondent (University F) who indicated that ... We have found that the take-up of messages is low because of the cost of reply - especially for mobile phones. Whilst we cannot control the price of such services, we can use the most appropriate software to ensure that we don't inflate the media message... In this respect, changing conditions towards mobile broadband technologies offered by service may mitigate the effects of this.

\section{Research Position}

This research outcome is modeled below in Figure 2, below and are linked to the literature in order to illustrate depth of the research outcomes. The main themes and sub-themes depicted in Figure 2 show the hierarchy from main theme through to sub-theme, but do not illustrate any relationship between the sub-themes. 


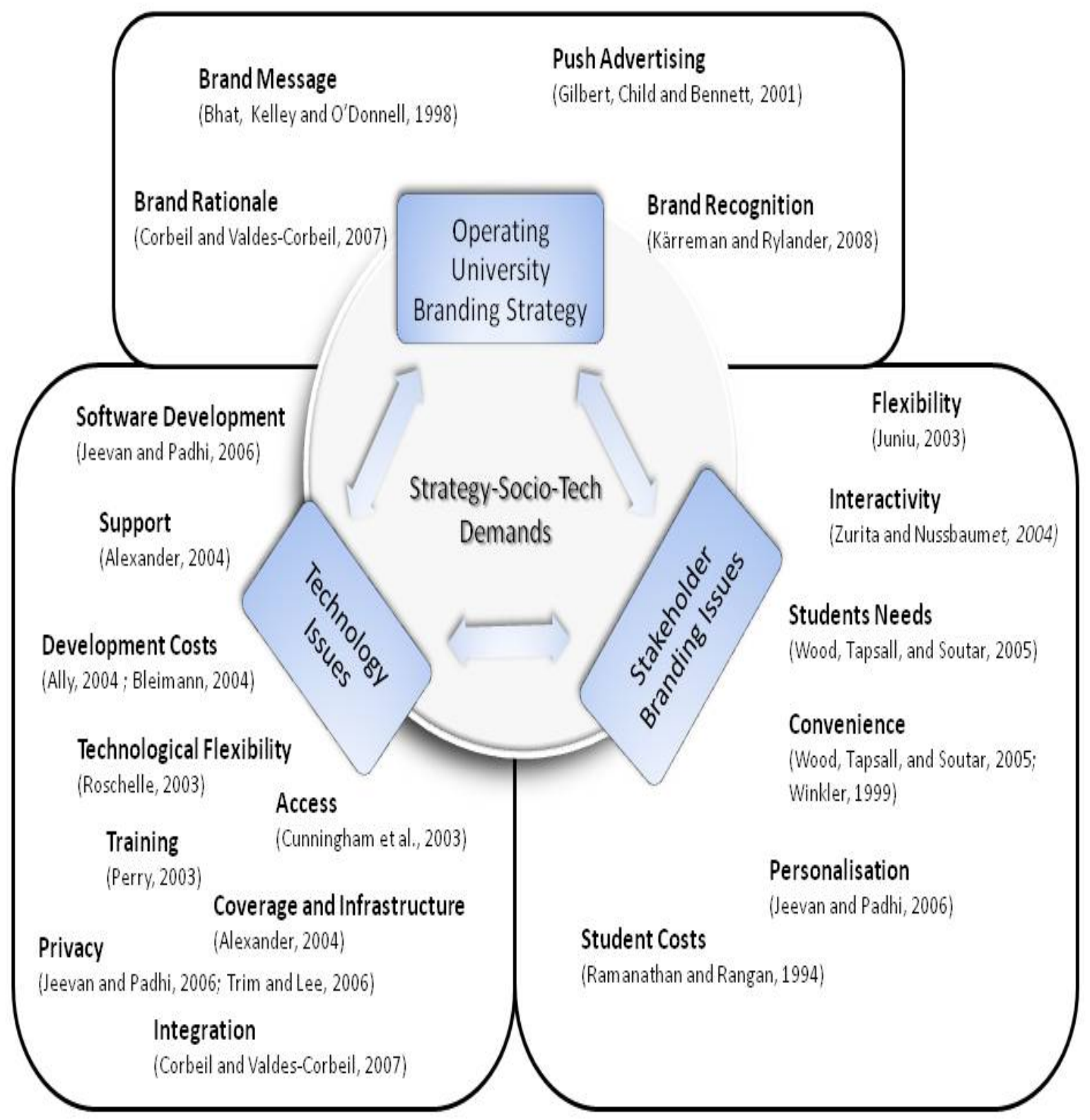

Figure 2. Research Outcomes

Whilst configuring the outcomes in this way, there does not appear to be an easy way to show how these various sub-themes are connected. Consequently, at attempt has been made in Figure 3, below in order to make sense of any relationships that may pertain to the research outcomes. This is further considered in Figure 3, below.

An explanation of Figure 3 starts with the Operating University Brand Strategy, where it would appear that the brand rationale determines the brand message, which is then pushed to students and a level of brand recognition occurs. However, future research would be needed to determine the meaning of this level of brand recognition. For the Stakeholder Branding Issues, flexibility and personalisation of the brand offering appears to lead to greater levels of interactivity, whilst providing convenience and satisfying students needs; mitigating this is 


\section{Mll Macrothink}

Journal of Management Research

ISSN 1941-899X

2011, Vol. 3, No. 1: E4

the issue of student related costs. For the Technology Issues, software development, technological flexibility and associated development costs leads to greater needs for training and support, which in turn leads to easier access, enhanced privacy, integration and wider potential coverage.

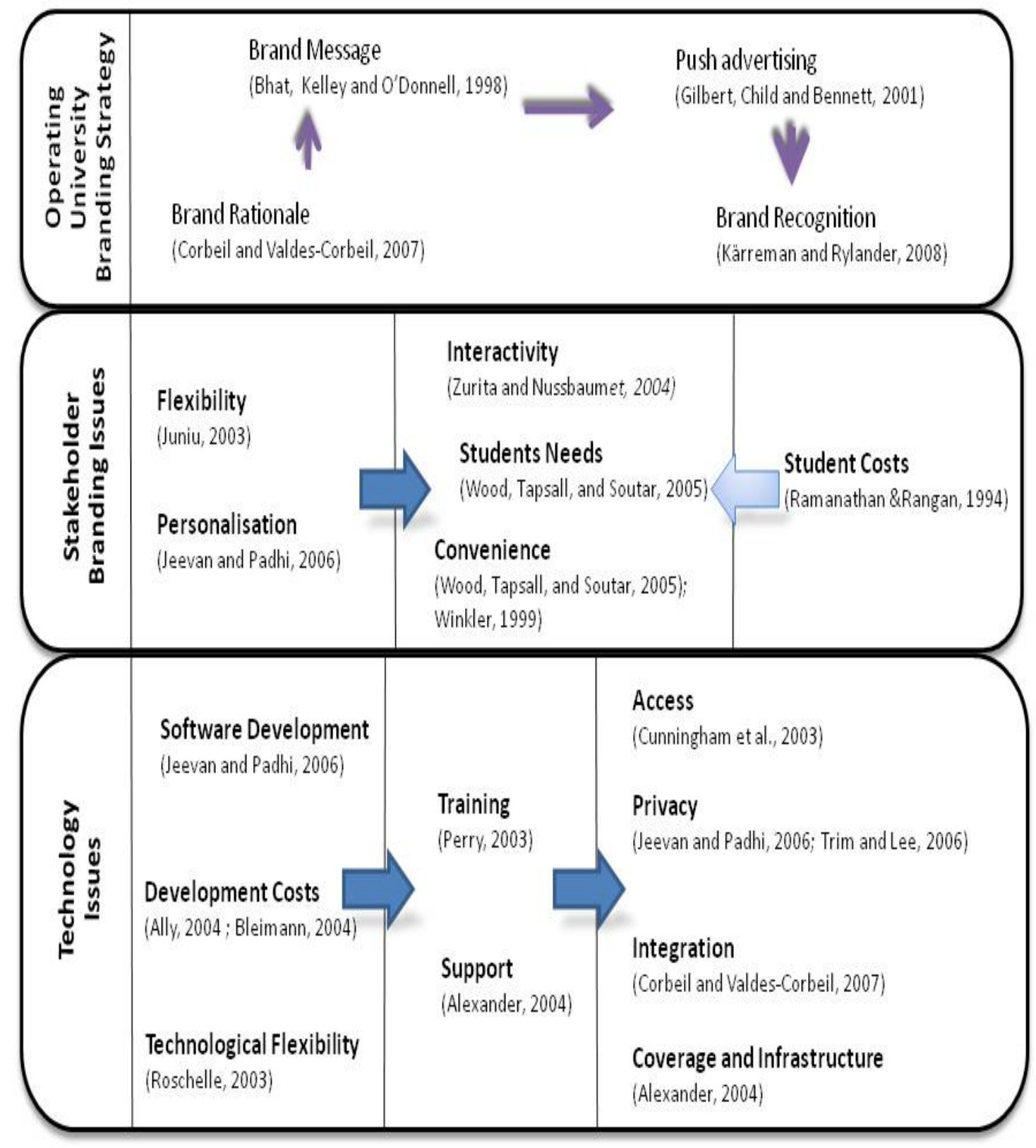

Figure 3 - Research Outcomes Analysis

The above statement of the results from this research suggests that m-Branding practices are only just being considered as part of university marketing strategy improvements. However, there does appear to be branding concerns raised by university management which must be assessed and evaluated if a more effective branding strategy is to be developed and utilised. 


\section{Future Issues}

m-Branding cannot be seen as an isolated aspect of the university marketing strategy (Ind, 1997) in terms of positioning (Aaker \& Joachimsthaler, 2000) and a communication strategy (Knapp, 2000). In order to effectively engage in branding practices requires knowledge and understanding of the effects of appropriate technological developments and their subsequent use. In this respect, an analysis of the future of m-Branding suggests:

1 Social-campus community development through mobile technology engagement utilising communication-intensive synchronous brand knowledge construction through peer-social reinforcement mechanisms.

2 Promotes the development of information literacy (Lippincott, 2005) and collaborative segment brand learning.

3 Student led m-Branding services may enhance whole-university performance.

4 Multi-tasking technology requires multi-channel branding initiatives.

5 Tracking technology can indicate when segment target opens, listens and/or responds to brand messages.

6 Viral-brand marketing techniques made easier to initiate as brand message personalised by the target.

7 Brand media can be selectively sent in response to target behaviour - which reduces media and message waste and keeps the brand fresh.

8 Provides opportunities for stakeholder/student involvement - "be the first to know".

9 Ensures live-synchronous data and real-time monitoring of target behaviour in terms of responses and non-responses, and allows immediate feedback about what works and what doesn't. e.g. Time of day responses, volumes, segments etc.

10 Requires changes in marketing vision and managing by data ethos.

11 Allows personalisation of content, as content drives m-Branding, but is mediated through access to appropriate technology and is not limited to university campus.

12 Supports both synchronous and asynchronous branding initiatives.

In terms of the specific outcomes contained here further research may be directed to appraising the level of inter-relationship between any of the identified themes and whether there is a hierarchy to the themes beyond those signified.

\section{Conclusion}

While there may be a valid criticism that universities may use the mobile device as a new channel because it is there, evidence presented here suggests that management may take the opportunity to relate the university brand to many students using personal media-messaging that underpins student's sense of belonging and psychological association with the respective university.

Personalisation (Sharples, 2002; Jeevan \& Padhi, 2006), and cost issues were raised (Ramanathan \& Rangan, 1994) as a major factor underpinning an m-Branding development directed at student segments. Additional efforts directed at reducing cost constraints may therefore persuade students to associate more effectively with the university brand, and this in itself suggests that those universities willing to make the brand message-response cost less 
for students, will receive more valuable responses in terms of numbers and potential engagement. Interactivity notions (Zurita \& Nussbaum, 2004) would indicate not only a need for students to connect socially and psychologically with the brand message but also follow through in terms of an appropriate response (Oblinger \& Oblinger, 2005). Clearly, university marketers appear to be aware of such issues but may not be in a position to equitably unify such segment involvement through lack of technology engagement.

The data would indicate that in order to move the university to a more informed framework for utilising m-Branding practices, more technical marketing involvement is required of management and staff. Support services linking m-Branding developments to the wider university community (stakeholders/students) through more effective measures designed to enhance and improve present best branding practices and attitudes may result in greater confidence associated with university branding strategies.

Thus, m-Branding reflecting a useful managerial tool would appear to require a more integrated approach in the Thai higher education system that results from a combination of technology, software, staff development and consequent student interest and engagement.

\section{References}

Ally, M. (2004). Using learning theories to design instruction for mobile learning devices. Proceedings of the Mobile Learning 2004 International Conference, Rome.

Aaker, D.A. (1991). Managing Brand Equity. The Free Press, New York, US.

Aaker, D.A. (1996). Building Strong Brands. The Free Press, New York, NY, US.

Aaker, D.A. \& Joachimsthaler, E. (2000) Brand Leadership. New York: Free Press, US.

Alexander, B. (2004). M-Learning: Emergent Pedagogical and Campus Issues in the Mobile Learning Environment. Research Bulletin, 16, Educause, US.

Bhat, S., Kelley, G.E. \& O’Donnell K.A. (1998). An investigation of consumer reactions to the use of different brand names. Journal of Product \& Brand Management, 7(1) 1998, pp.41-50.

Baker, S. (2003). New Consumer Marketing: Managing a Living Demand System, Wiley, Chichester, US.

Balshem, M. (1991). Cancer, control and causality: Talking about cancer in a working class community. American Ethnologist, 18, pp.152-172.

Barnes, S.J. (2002). The mobile commerce value chain: analysis and future developments, International Journal of Information Management, 22, pp.91-108.

Benady, A. (2005). Global selling: Nestle’s new flavour of strategy. Financial Times, 13 February, 13.

Belanger, C., Mount, J. \& Wilson, M. (2002). Institutional image and retention. Tertiary Education and Management, 8 (3), p.217. 
Bhat, S., Kelley, G.E. \& O’Donnell, K.A. (1998). An investigation of consumer reactions to the use of different brand names. Journal Of Product \& Brand Management, 7(1), pp.41-50.

Binsardi, A. \& Ekwulugo, F. (2003). International marketing of British education: Research on the students' perception and the Thai market penetration. Marketing Intelligence Planning, 21(5), pp.318-327.

Bleimann, U. (2004). Atlantis University: a new pedagogical approach beyond e-learning. Campus-Wide Information Systems, 21(5), pp.191-195.

British Council, (2008). [Online] Available: http://www.britishcouncil.org/eumd-information-background-Thailand.htm (October 12, 2008)

Buston K. (1999). NUD*IST in action: its use and its usefulness in a study of chronic illness in young people. In: Bryman A, Burgess RG, editors. Qualitative Research. Vol. 3, Analysis and Interpretation of Qualitative Data. London: Sage. pp.183-202.

Canterbury, R.M. (1999). Higher education marketing: a challenge. The Journal of College Admission, 165, pp.22-30.

Carchiolo, V., Longheu, A., Malgeri, M. \& Mangioni, G. (2003). Courses personalization in an e-learning environment. Proceedings of the 3rd International Conference on Advanced Learning Technologies, 9-11 July 2003, Athens, Greece, IEEE, pp.252-3.

Carman, J. M. (1990). Consumer Perceptions of Service Quality: An Assessment of the SERVQUAL Dimensions. Journal of Retailing, 66(1), pp.33-55.

Carpenter J. (2008). Metaphors in Qualitative Research: Shedding Light or Casting Shadows? Research in Nursing \& Health, 31, pp.274-282.

Caruana, A., Ramaseshan, B. \& Ewing M.T. (1999). Market orientation and performance in the public sector. Journal of Global Marketing, 12(3), pp.59-75.

Cassell, C. \& Symon, G. (2004). Essential Guide to Qualitative Methods in Organizational Research, Sage, UK.

Cayla, J. \& Eckhardt, G.M. (2007). Asian brands without borders: regional opportunities and challenges. International Marketing Review, 24(4), pp.444-456.

Cheng, K., Kambayashi, Y., Lee, S.T. \& Mohania, M.K. (2000). Functions of a Web warehouse, Proceedings of the International Conference on Digital Libraries: Research and Practice, 13-16 November 2000, Kyoto, Japan, IEEE, pp.160-167.

Chernatony, L. \& McDonald, M. (1998). Creating Powerful Brands, 2nd ed., Butterworth-Heinemann, Oxford.

Chipkin, H. (1997). Richard Branson talks about marketing, HSMAI Marketing Review, Summer, pp.12-15.

Collis, B. \& Moonen, J. (2001). Flexible Learning in a Digital World: Experience and 
Expectations. London: Kogan Page.

Corbeil, J.R. \& Valdes-Corbeil, M.E. (2007). Are you ready for mobile-learning? Educause Quarterly, 2, pp.51-58.

Cubillo, J., Sanchez, J. \& Cervino J. (2006). International students' decision-making process. International Journal of Educational Management, 20(2), pp.101-115.

Cunningham, S., Ryan, Y., Stedman, L., Tapsall, S., Bagdon, K., Flew, T. \& Coaldrake, P. (2003). The Business of Borderless Education, DETYA, Canberra.

Dahn, I. \& Schwabe, G. (2002). Personalizing textbooks with slicing technologies concept, tools, architecture, collaborative use. Proceedings of the 35th International Conference on System Sciences, (HICSS), 7-10 January 2002, Mauri, HI, USA, IEEE, p.10.

Dadarlat, V., Coffey, T. \& Ivan, C. (2002). A personalized approach for teaching Web-based curriculum in Communications \& Computer Networks. Proceedings of the Canadian Conference on Electrical and Computer Engineering (IEEE CCECE 2002), 12-15 May 2002, Winnipeg, MB, Canada, IEEE, 2, pp.732-737.

Daniel, D. (2000). Information Quality and its interpretative Reconfiguration as a Premise of Knowledge Management in Virtual Organizations. In Y. Malhotra (Ed.). Knowledge management and virtual organizations (365-379). Hershey PA: Idea Group Publishing

Delamothe, T. (2000). Quality of web sites: kitemarking the west wind. BMJ, 321(7) October, pp.843-844.

Eagle, L. \& Brennan, R. (2007). Are students customers? TQM and marketing perspectives. Quality Assurance in Education, 15(1), pp.44-60.

Foskett, N. (2002). Marketing, in Bush T. \& Bell L. (Eds), The Principles and Practice of Educational Management, Paul Chapman, London, pp.241-257.

Freeman, I. \& Thomas, M. (2005). Consumerism in education: A comparison between Canada and the United Kingdom. International Journal of Educational Management, 19(2), pp.153-177.

Ghodeswar, B.M. (2008). Building brand identity in competitive markets: a conceptual model. Journal of Product \& Brand Management, 17(1), pp.4-12.

Gibb, A.A. (1996). Entrepreneurship and small business management: can we afford to neglect them in the twenty-first century business school. British Journal of Management, 7(4), pp.309-321.

Gibbons, M. (1998). A commonwealth perspective on the globalisation of higher education, in Scott, P. (Ed.), The Globalization of Higher Education, Society for Research into Higher Education and Open University Press, Buckingham, pp.70-87.

Gilbert C. (2006). A Vision for Teaching and Learning in 2020. Teaching and Learning in 2020 Review Group, UK. 
Gilbert, D., Child, D. \& Bennett, M. (2001). A qualitative study of the current practices of 'no-frills' airlines operating in the UK. Journal of Vacation Marketing, 7, pp.302-315.

Glaser, B.G. (1992a). Basics of Grounded Theory Analysis: Emergence Versus Forcing. Mill Valley, CA: Sociological Press, US.

Glaser, B.G. (2004). Naturalist inquiry and grounded theory. Forum: Qualitative Social Research, 5(2). [Online] Available: http://qualitative-research.net/fqs-texte/1-04/1-04glaser-e.htm (March 5, 2010)

Glaser, B.G. \& Strauss, A.L. (1967). The Discovery of Grounded Theory: Strategies for Qualitative Research. Aldine Transaction, US.

Gonzalez C. (2008). Conceptions of, and approaches to, teaching online: a study of lecturers teaching postgraduate distance courses. Higher Education, DOI 10.1007/s10734-008-9145-1

Gray, L. (1991). Education Marketing. Open University Press, Buckingham, UK.

Gray, B., Fam, K. \& Llanes, V. (2003b). Branding universities in Chinese markets. Journal of Product and Brand Management, 12(2), pp.13-30.

Gray, B.J., Fam, K.S., \& Llanes, VA. (2003b). Cross cultural values and the positioning of international education brands. Journal of Product and Brand Management, 12(2), pp.108-119.

Gray J. \& Wilcox B. (1995). Good Schools, Bad Schools, Open University Press, UK.

Groves M., Jarnigan M., \& Eller K. (1998). But how do we use it?: Discovering hidden barriers and unanticipated successes in integrating computers in a preschool curriculum. Proceedings of the Families, Technology and Education Conference, Chicago, October/November, pp.57-62.

Hamann, D. Williams R.L. \& Omar M. (2007). Branding strategy and consumer high-technology product. Journal of Product \& Brand Management, 16(2), pp.98-111.

Hambrecht and Co., W.R. (2000). Corporate e-Learning: Exploring a New Frontier, Hambrecht \& Co, New York, US.

Harrel, G.D. \& Fors, M.F. (1995). Marketing services to satisfy internal customers. Logistics Information Management, 8(4), pp.22-27.

Harrison C., Comber C., Fisher, T., Haw, K.; Lewin, C., Lunzer, E., McFarlane, A., Mavers, D., Scrimshaw, P.,Somekh, B., and Watling R. (2002). ImpacT2: The Impact of Information and Communication Technologies on Pupil Learning and Attainment. ICT in Schools Research and Evaluation Series, No. 7. London: DfES/BECTa. [Online] Available: http://www.becta.org.uk/page documents/research/ImpaCT2 strand2 report.pdf (April 9, 2010)

Harwood, T.G. \& Garry, T. (2003). An overview of content analysis. The Marketing Review, 3(4), pp.479-498. 


\section{Macrothink}

Journal of Management Research

ISSN 1941-899X

2011, Vol. 3, No. 1: E4

Hemsley-Brown, J.V \& Oplatka, I. (2006). Universities in a competitive global marketplace: a systematic review of the literature on higher education marketing. International Journal of Public Sector Management, 19(4), pp.316-338.

Hesketh, A.J. \& Knight, P.T. (1998). Secondary School Prospectuses and Educational Markets. Cambridge Journal of Education, 28(1), pp.21-23.

Ho, H. \& Hung, C. (2008). Marketing mix formulation for higher education. International Journal of Educational Management, 22(4), pp.328-340.

igi-global.com

(2008).

[Online]

Available:

http://www.igi-global.com/books/additional.asp?id=4754\&title=Preface\&col=preface (July 10, 2010)

Ind, N. (1997). The Corporate Brand. Houndmills: Macmillan, US.

Ind, N. (2003). Beyond Branding: How the New Values of Transparency and Integrity Are Changing the World of Brands, Biddles, Guilford, King's Lynn and London, UK.

Ivy, J. (2001). Higher education institution image: a correspondence analysis approach. The International Journal of Educational Management, 15(6/7), pp.276-282.

James P.T.J. (2008). Brand Marketing Practices in Thai Higher Education: Competing in Recessive Environments for Domestic and International Students. BU Executive Journal, July-December, 2008, Oct-Dec, 28(4), pp.56-62.

Jeevan, V.K.J. \& Padhi, P. (2006). A selective review of research in content personalization. Library Review, 55(9), pp.556-586.

Jiang, P. (2004). The role of brand name in customization decisions: a search vs. experience perspective. Journal of Product \& Brand Management, 13(2), pp.73-83.

Judson, K., Aurand, T. \& Gorchels, L. (2006). Building a University Brand from Within, Journal of Marketing for Higher Education, 16(1), pp.97-114.

Juniu, S. (2003). Implementing wireless technology in the classroom: the iPAQ project. College Planning and Management, 6, (10), pp.38-40.

Kapferer, J.N. (1992). Strategic Brand Management. Kogan Page: London.

Kapferer, J.N. (1995). Brand confusion: empirical study of a legal concept. Psychology \& Marketing, 12 (6), pp.551-568.

Kapferer, J.N. (2004). Brand NEW world, brand equity, The Economic Times, June 30, Mumbai.

Kärreman, D. \& Rylander, A. (2008). Managing Meaning through Branding - the Case of a Consulting Firm. Organization Studies, 29, pp.103-125. 
Keegan, D. (2003). The future of learning: From eLearning to mLearning. Hagen: Femstudienforchung, Germany. [Online] Available: http://learning.ericsson.net/mlearning2/old_sites/book.html (November 10, 2008)

Knapp, D.E. (2000). The Brand Mindset, McGraw-Hill, New York, US.

Kramer, J., Noronha, S. \& Vergo, J. (2000). A User-Centered Design Approach to Personalization. Communications of the ACM, 43(8), pp.45-48.

Lancaster, G. \& Reynolds, P. (2002). Marketing - The One Semester Introduction, Butterworth-Heinemann, Oxford, UK.

Lippincott, J. (2005). Net generation students and libraries, in Oblinger, D.G. \& Oblinger, J.L. (Eds), Educating the Net Generation, Educause. [Online] Available: www.educause.edu/educatingthenetgen/5989 (May 17, 2009)

MacGregor, K. (2000). Dire results slash numbers. The Times Higher Education Supplement, $28^{\text {th }}$ January, 15.

Madu, C.N. \& Jacob, R.A. (1999). The internet and global cultural transformation. Foresight, 1(1), pp.63-71.

Mahoney, J. (1998). Higher education in a dangerous time: will technology really improve the university? Journal of College Admission, 161, Fall, pp.24-30.

Maringe, F. (2005). Interrogating the crisis in higher education marketing: the CORD model. International Journal of Educational Management, 19(7), pp.564-578.

Mazzarol, T. (1998). Critical success factors for international education marketing. International Journal of Educational Management, 12(4), pp.163-175.

Mazzarol, T. \& Soutar, G. (2001), The Global Market for Higher Education: Sustainable Competitive Strategies for the New Millennium, Edward Elgar, Cheltenham.

Meek, V. \& Wood, F.Q. (1997). The market as a new steering strategy for Australian Higher Education. Higher Education Policy, 10(3-4), pp.253-274.

Miles, M.B. \& Huberman, A.M. (1994). Qualitative data analysis: An expanded sourcebook, (2nd ed.). Thousand Oaks, CA: Sage, US.

MOE - Ministry of Education, Thailand. (2008). [Online] Available: http://www.moe.go.th/icpmoe/Other/Report/roadmap.pdf (January 22, 2010)

Nicholls, J; Harris, J; Morgan, E; Clarke, K; \& Sims, D. (1995). Marketing higher education: the MBA experience. International Journal of Educational Management, 9(2), pp.31-38.

Nyiri, K. (2002). Towards a philosophy of m-learning. Proceedings of the IEEE International Workshop on Wireless and Mobile Technologies in Education. (WMTE’02). August 29-30, Växjö University, Växjö, Sweden.

Oblinger, D. \& Oblinger, J. (2005). Is it age or IT: first steps toward understanding the net 
generation, in Oblinger, D.G. \& Oblinger, J.L. (Eds), Educating the Net Generation, Educause. [Online] Available: www.educause.edu/educatingthenetgen/5989 (January 9, 2010)

Olatokun, M.W. \& Bodunwa, I.O. (2006). GSM usage at the University of Ibadan. The Electronic Library, 24(4), pp.530-547.

Perry, D (2003). Handheld Computers (PDAs) in Schools. [Online] Available: http://www.becta.org.uk/research/reports/docs/handhelds.pdf (December 14, 2008)

Perugini, S. \& Ramakrishnan, N. (2003). Personalizing Web sites with mixed-initiative interaction. IT Professional, 5(2), March-April, pp.9-15.

Petsas, S., Tzovaras, D., Makris, L. \& Strintzis, M.G. (2001). WAP-based personalised health care services. Proceedings of the 23rd International Conference of the IEEE Engineering in Medicine and Biology Society, 25-28 October 2001, Istanbul, Turkey, IEEE, 4, pp.3536-2539.

Qu, H.T. \& Shen, R.M. (2002). The design and implementation of personalized learning navigation system. Proceedings of the International Conference on Machine Learning and Cybernetics, 4-5 November 2002, Beijing, China, IEEE, 3, pp.1310-1313.

Ramanathan, S. \& Rangan, P.V. (1994). Architectures for personalized multimedia, IEEE Multimedia, 1(1), pp.37-46.

Reeves, T.K. \& Harper, D. (1981). Surveys at Work. McGraw-Hill, UK.

Rishi, R. (2007). Always Connected, But Hard to Reach. Educause Quarterly, 2, pp.7-9.

Roschelle, J (2003). Unlocking the learning value of wireless mobile devices. Journal of Computer Assisted Learning, 19(3), pp.260-272.

Samiee, S. (1998). The internet and international marketing: is there a fit? Journal of Interactive Marketing, 12(4), pp.5-21.

Schwabe, D., Rossi, G. \& Guimaraes, R. (2002). Cohesive design of personalized Web applications, Internet Computing, 6(2), March-April, pp.34-43.

Sekikawa A., Aaron D.J., Acosta B., Sa E., \& LaPorte R.E. (2001). Does the perception of downloading speed influence the evaluation of web-based lectures? Public Health, 115, pp.152-156.

Sharples, M. (2002). Disruptive devices: mobile technology for conversational learning. International Journal of Continuing Engineering Education and Life Long Learning, 12(5/6), pp.504-520.

Smith, D., Scott, P. \& Lynch, J. (1995). The academic service provider: Is the customer 'always right'? Journal of Higher Education Policy and Management, 21(2), pp.193-203.

Straus, A., and Corbin, J. (1990). Basics of qualitative research. Newbury Park, CA: Sage, US.

Swaminathan, V., Fox, R.J. \& Reddy, S.K. (2001). The impact of brand extension 
introduction on choice. Journal of Marketing, 65, October, pp.1-15.

Tagwireyi, S. (2000). Decline in students hits universities. [Online] Available: www.sn.apc.org/wmail/issues/ooo128/news40.html (March 1, 2010)

Tapp, A., Hicks, K. \& Stone, M. (2004). Direct and database marketing and customer relationship management in recruiting students for higher education. International Journal of Non-profit and Voluntary Sector Marketing, 9(4), pp.333-345.

Temporal, P. (2000). Branding in Asia, John Wiley \& Sons, Singapore.

Trim, P. \& Lee Y. (2006). An internationally focused synthesised marketing strategy underpinned by qualitative research. Qualitative Market Research: An International Journal, 9(3), pp.203-224.

Tsai, C.J., Tseng, S.S. \& Chen, S.H. (2000). Design and implementation of a personalized service management system. Proceedings from the International Conference on Systems, Man, and Cybernetics, 8-11 October, Nashville, TN, USA, IEEE, 1, pp.542-547.

Tull, D.S. \& Hawkins, D.I. (1990). Marketing Research: Measurement and Method. Macmillan, UK.

Turley, L.W. \& Moore, P.A. (1995). Brand name strategies in the service sector. Journal of Consumer Marketing, 12, pp.42-50.

Twitchell, J.B. (2002). The branding of higher ed. Forbes, 170(11), p.50.

Wainwright E.J. (2005). Strategies for university academic information and service delivery. Library Management, 26(8/9), pp.439-456.

Wæraas, A. (2008). Can public sector organizations be coherent corporate brands? Marketing Theory, 8(2), pp.205-221.

Walsh, S.P., White, K.M., \& Young, R.M. (2008). Over-connected? A qualitative exploration of the relationship between Australian youth and their mobile phones. Journal of Adolescence, 31, pp.77-92.

Wernick, A. (2006). Rebranding Harvard. Theory, Culture \& Society, 23(2-3), p.566.

Williams, G.L. (1995) 'The “marketization” of higher education: Reforms and potential reforms in higher education finance'. In Dill, D.D. \& Sporn, B. (eds.), Emerging Patterns of Social Demand and University Reform: Through a Glass Darkly. Oxford: Pergamon Press, UK.

Wilson S. \& Velayutham K. (2008). Repositioning institutional approaches to technology in the context of Web 2.0, Personal Learning Environments and Utility Computing: A cybernetic approach.

[Online]

Available: http://mfeldstein.com/3repositioning-institutional-approaches-to-technology-in-the-context-of -web-20-personal-learning-environments-and-utility-computing-a-cybernetic-approach/ (June 8, 2010) 


\section{Macrothink}

Journal of Management Research ISSN 1941-899X 2011, Vol. 3, No. 1: E4

Winkler, A.M. (1999). Warp-speed Branding: The Impact of Technology on Marketing, John Wiley \& Sons, New York, NY.

Wood, B., Tapsall, S.M. \& Soutar, G.N. (2005). Borderless education: some implications for management. International Journal of Educational Management, 19(5), pp.428-436.

Zhang, D.S. \& Shijagurumayum, S. (2003). Personalized content delivery to mobile devices. Proceedings of the International Conference on Systems, Man and Cybernetics, 5-8 October 2003, Washington, DC, USA, IEEE, 3, pp.2533-2538.

Zurita, G. \& Nussbaum, M. (2004). Computer supported collaborative learning using wirelessly interconnected handheld computers. Computers and Education, 42(3), pp.289-314. 